\title{
Effect of the Addition of Thyme "Thymus vulgaris" Leaves on the Sensory and Nutritional Quality of Lamb Meat
}

\author{
N. Ayeb ${ }^{1,2}$, Z. Jrad², H. Hajji', S. Arroum², I. Fguiri², \\ M. Dbara ${ }^{2}$, M. Hammadi², H. El-Hatmi ${ }^{2,3}$,T. Khorchani ${ }^{2}$
}

10.18805/ajdfr.DRF-247

\begin{abstract}
Background: The shelf life of meat products can be increased by adding synthetic antioxidants. These antioxidants have long been used, but their safety has recently come into dispute due to a suspected carcinogenic potential. This is why meat technologies have extracted new natural antioxidants from spices and herbs, which are the best alternatives to synthetic compounds. So, the addition of natural flavors (essential oils, powder or extract of aromatic plants) to the meat can improve organoleptic quality and consumer acceptability.

Methods: This study was conducted to evaluate the physicochemical and organoleptic qualities of meat fortified with thyme powder. With this purpose, 16 samples from four muscles of legs from 4 lambs were used in this work. The muscles were divided into two groups, control group (meat without any supplementation) and thyme group (meat supplemented with thyme). In this later group, a dose of $5 \%$ of ground thyme dry leaves was added to the meat.

Result: Results showed no significant differences were found among groups for cooking loss, but was slightly higher for meat treated with thymus (33.29 vs. $28.36 \%$ ). No significant differences between the two groups were observed for the ash, fat and crude protein contents of the meat. At the same manner, no effect was observed on meat lightness $(L)$ and yellowness $\left(b^{*}\right)(P>0.05)$, on the contrary, redness $\left(\mathrm{a}^{*}\right)$ of the meat was affected by addition of thyme $(11.28 \pm 1.23$ vs. $23.06 \pm 9.80)$. Also, significant $(P<0.05)$ differences were observed in texture scores, flavor, color and taste between control and the $5 \%$ thyme-supplemented meat samples. The overall acceptability of supplemented meat samples was highest $(\mathrm{P} \leq 0.05)$ as compared to control $(5.91 \pm 2.32$ vs. $4.35 \pm 2.66)$. In conclusion, addition of thyme leaves did not affect the physical and chemical properties of meat, except for redness and improved sensory quality.

Key words: Composition, Leaves, Meat, Natural antioxidants, Quality, Sheep, Species, Thyme.
\end{abstract}

\section{INTRODUCTION}

Meat and its derivatives occupy a prominent place in our diet for nutritional reasons. The richness of the meat in proteins with high biological value makes it an indispensable food for a balanced diet. The short shelf life of fresh meat is linked to a complex process of chemical and microbiological reactions that can favor quality degradation. It is necessary to slow down these various weathering mechanisms by different techniques, such as salting, drying, smoking and the addition aromatic and medicinal plants. In this context, many raw plant materials such as herbs and aromatic plants, which have been used for a long time as a cure for several diseases, are added regularly to food. In addition, it is well known that these herbs can help with the intake of antioxidants to minimize health hazards when eating high fat foods such as meat (Nieto et al., 2010). In recent decades, aromatic extracts and essential oils have become sources of natural antioxidants, antimicrobial and antiseptic agents due to their antiseptic properties (Bandoniene et al., 2000). Currently, BHA (butylated hydroxyanisole) and BHT (butylated hydroxytoluene) are not permitted as an additive in meat and poultry products. However, the addition of aromatic and medicinal plants can ensure better conservation by the antioxidant and antibacterial action of certain compounds of the foodstuffs and to improve the taste
${ }^{1}$ Regional Center for Agricultural Research (CRRA) Sidi Bouzid, Tunisia.

${ }^{2}$ Livestock and Wildlife Laboratory, Institute of Arid Regions, Medenine, university of Gabes, Tunisia.

${ }^{3}$ Agro-food Department, Institute of Applied Biology of Medenine, University of Gabes, Tunisia.

Corresponding Author: N. Ayeb, Regional Center for Agricultural Research (CRRA) Sidi Bouzid, Tunisia.

Email: naziha.ayeb@yahoo.fr

How to cite this article: Ayeb, N., Jrad, Z., Hajji, H., Arroum, S., Fguiri, I., Dbara, M., Hammadi, M., El-Hatmi, H. and Khorchani, T. (2022). Effect of the Addition of Thyme "Thymus vulgaris" Leaves on the Sensory and Nutritional Quality of Lamb Meat. Asian Journal of Dairy and Food Research. DOI: 10.18805/ajdfr.DRF-247.

Submitted: 11-08-2021 Accepted: 26-11-2021 Online: 07-01-2022

quality. The demand for all-natural additives has focused attention on the search for antioxidant extracts from plants (Dapkevicius et al., 1999). Thyme, rosemary, ginger and sage, are widely used as natural preservatives for their antioxidant, antifungal properties. This work aims to study the effect of thyme addition on the physicochemical characteristics and the sensory quality of lamb meat. 


\section{MATERIALS AND METHODS}

Dried leaves of thyme (Thymus vulgaris) were purchased in spring (at the time of the experiment) from a single vendor at the local traditional market in Medenine (Tunisia), cleaned and ground. There were 16 samples from 4 sheep. Four leg muscles of the left $1 / 2$ carcass were studied and the sampling was repeated for 4 weeks (the number of which was 4 legs $\times 4$ weeks $=16$ samples). Each thigh was deboned, cut into pieces and then chopped by an electric chopper and divided into two groups: the control group (meat without any supplementation) and thyme group (meat supplemented with $5 \%$ thyme).

\section{Chemical analysis of thyme \\ Determination of physical and chemical characteristics of meat}

\section{Determination of $\mathrm{pH}$}

The $\mathrm{pH}$ measurement was determined according to the AOAC method (1995). In this method $10.0 \mathrm{~g}$ of the meat muscle was homogenized by manual porcelain grinder in $100 \mathrm{~mL}$ distilled water and the mixture filtered. The $\mathrm{pH}$ of the filtrate was measured using a $\mathrm{pH}$ meter (inoLab, Weilheim, Germany) after calibrating with two buffers $(\mathrm{pH}=7.00$ and $\mathrm{pH}=4.01)$.

\section{Moisture content determination}

According to AOAC method (1995), a sample of meat was dried at $105^{\circ} \mathrm{C}$ in an oven for $24 \mathrm{~h}$ to determine dry matter (DM) content.

\section{Ash determination}

Ash was analysed by incineration of $5 \mathrm{~g}$ of meat placed in a muffle furnace maintained at $550^{\circ} \mathrm{C}$ for $6 \mathrm{~h}$.

\section{Crude protein determination}

Total nitrogen $(N)$ content was determined by micro Kjeldahl method using the J.P Selecta digestion unit and PRO-NITRO II (Barcelona, Spain) distilling unit according to AOAC (1995). The Kjeldahl method is divided into three steps, the first step was mineralization and it is done in the presence of sulfuric acid. One gram of the ground meat was introduced into a $300 \mathrm{ml}$ digestion tube and $12 \mathrm{ml}$ of sulfuric acid and 1 $\mathrm{g}$ of catalyst added. The tube was placed in the digestion unit to undergo heating at $450^{\circ} \mathrm{C}$ for $4 \mathrm{~h}$. The product obtained after digestion must be colorless. Second step was the distillation: after digestion, the tubes were placed in a distiller, which releases the ammoniacal nitrogen after addition of $50 \mathrm{ml}$ of $35 \%$ sodium hydroxide solution; the vapour was recovered in a $10 \mathrm{ml}$ of boric acid solution. The last step was titration: The ammonia collected in a solution of boric acid was titrated using a manual burette, which makes it possible to determine the volume of $0.1 \mathrm{~N}$ hydrochloric acid necessary to titrate the amount of ammoniac distilled. The titration was done until the solution of HCL. Crude protein was calculated as $\mathrm{N} \times 6.28$.

\section{Cooking loss determination}

Cooking loss $(\mathrm{CL})$ was measured in the muscle of a different cut. Meat samples were weighed (Wi), held in plastic bags and then immersed in a water-bath $\left(30 \mathrm{~min} / 75^{\circ} \mathrm{C}\right)$. After cooking, the sample weights were recorded. Cooking loss was calculated using the following formula:

$$
\text { Cooking loss }(\mathrm{CL})(\%)=
$$

Weight before cooking (wi) - Weight after cooking (wf) Weight before cooking (wi) 100

\section{Fat determination}

Lipid extraction of meat was carried out according to a Hara and Radin method (1978) using the two solvent mixture, hexane/isopropanol (3:2, v/v).

\section{Color values}

Color parameters $\left(L, a^{*}, b^{*}\right)$ were measured in meat using a Minolta CR 400 color meter calibrated to a standard white plate. $L$ is the lightness coordinate and it is a measure of the reflected light $(100=$ all light reflected; $0=$ all the light absorbed); $a^{*}$ (positive values: red color, negative values: green color) and $b^{*}$ (positive values: yellow color, negative values: blue color). Measurements were made perpendicular to the fillet surface at five different locations per sample; mean values $\left(L, a^{*}\right.$ and $\left.b^{*}\right)$ from the samples were analyzed and triplicate fillets were analyzed to obtain an average colorimetric value.

\section{Sensory analysis}

Meat was cooked in electric oven. After cooking, each portion was wrapped in aluminum foil and identified with a single random 3-digit code. The samples were kept warm until serving within 5 to $7 \mathrm{~min}$ after cooking. They were subjected to sensory evaluation by 48 panelists. Meat samples were assessed under incandescent light for their appearance, color, flavor, juiciness and texture. Panelists received a set of 2 samples per session, representing the 2 different samples (control and thyme meat). Each sample was evaluated in duplicate. The panelists were asked to drink natural water at the beginning of the sensory evaluation and between samples to try to make the palate conditions similar for each sample. Meat traits are rated on the basis of $10 \mathrm{~cm}$ unstructured lines with the 10 points scale $(0=$ lower intensity, 10 for higher intensity). Scores were the distances (cm) from the left anchor point. At the end of sensory evaluation, panelists were asked to rank overall meat acceptability.

\section{Statistical analysis}

All variables (physicochemical composition and sensory analysis) were subjected to analysis of variance (ANOVA) using the statistical package SPSS 20. Duncan's multiple range tests were used to test for differences between means $(P<0.05)$. 


\section{RESULTS AND DISCUSSION}

\section{Chemical composition of meat}

Chemical composition results of meat (control vs. supplemented with thymus) are presented in Table 1. The $\mathrm{pH}$ value was not significantly affected $(\mathrm{P}>0.05)$. Jin et al. (2006) found that the $\mathrm{pH}$ value of the sausages was decreased by the addition of thyme and rosemary. On the contrary, Hijazeen and Rawashdeh (2017) showed that the addition of essential oils of rosemary did not affect $(P>0.05)$ the $\mathrm{pH}$ value of the meat. The $\mathrm{pH}$ values in our study, are considered slightly high since they exceed the ultimate $\mathrm{pH}$ 5.8 as reported by Normand et al. (2005). Indeed, the high $\mathrm{pH}$-value of meat $(\geq 6)$ is a problem in commercial presentation and has poor conservation. This meat is completely suitable for consumption but in a short period. Cooking loss, which is one of the meat quality parameters, refers to the reduction in weight of meat during the cooking process (Jama et al., 2008; Adam et al., 2010). No significant differences were found among groups for cooking loss values. The levels of cooking loss are slightly higher for meat control group than that of meat supplemented with thyme (33.29 vs. $28.36 \%$ ). The cooking loss values found in this study are within the range of the standard for technologically good meats (18-34\%) as reported by Dhanda et al. (1999) and Kannan et al. (2001). No significant differences were observed between groups for the ash, fat and crude protein contents. Supplementation of thyme decreased significantly the moisture compared with the control.
The effects of thyme supplementation on meat color parameters (lightness, redness and yellowness) are shown in Table 1. No effect was observed on thigh meat lightness and yellowness $(P>0.05)$, on the contrary, the redness of the meat was affected by the addition of thyme. However, Changes in meat color are due to the oxidation of red oxymyoglobin to metmyoglobin, which gives the meat an unattractive brown color. Some reports demonstrated that natural antioxidants could postpone meat color loss by extending the red color ( $\left.a^{*}\right)$ (Kannan et al., 2001). Similarly, using extracts of rosemary and sage reduced the lipid oxidation and cholesterol concentration of broiler meat during storage for nine days (Velasco et al., 2011).

\section{Sensory quality}

The effects of thyme on the sensory evaluation of meat samples are presented in Table 2. Except for juiciness, other parameters such as aroma, flavor, color, taste and overall acceptability scores were highest $(P<0.05)$ for $5 \%$ thyme supplemented meat samples as compared with the control. These results were consistent with those of Abdel Hamied et al. (2003), who indicated that organoleptic properties of minced beef fortified with rosemary were acceptable by the panelists compared to unfortified ones. Also, Jin et al. (2006) found that addition $(0.2 \%)$ of rosemary essential oil to cooked chicken produced an acceptable odor and taste. The majority of the evidence suggests that there is little or no effect of pre slaughter growth rate on meat tenderness (Abdel Hamied et al., 2009) and the relationship may however, depend on the cooking method that is used.

Table 1: Chemical composition and color coordinates of meat lambs with or without thyme extract.

\begin{tabular}{|c|c|c|c|c|}
\hline & & Meat control & Meat supplemented with thyme & $P$ value \\
\hline \multicolumn{2}{|l|}{$\mathrm{pH}$} & $6.01 \pm 0.13$ & $5.99 \pm 0.15$ & 0.300 \\
\hline \multicolumn{2}{|c|}{ Dry matter (\%) } & $29.70 \pm 3.56^{a}$ & $27.94 \pm 0.68^{b}$ & 0.018 \\
\hline \multicolumn{2}{|c|}{ Ash (\%) } & $8.84 \pm 3.20$ & $4.56 \pm 0.35$ & 0.404 \\
\hline \multicolumn{2}{|c|}{ Cooking loss (\%) } & $28.36 \pm 10.50$ & $33.29 \pm 7.54$ & 0.900 \\
\hline \multicolumn{2}{|c|}{ Fat (\%) } & $6.13 \pm 0.57$ & $5.87 \pm 1.03$ & 0.701 \\
\hline \multicolumn{2}{|c|}{ Protein $(\%)$} & $21.96 \pm 2.51$ & $23.45 \pm 1.59$ & 0.414 \\
\hline & $\mathrm{L}$ & $52.91 \pm 9.19$ & $48.94 \pm 7.23$ & 0.297 \\
\hline \multirow[t]{2}{*}{ Color } & $a^{*}$ & $23.06 \pm 9.80^{a}$ & $11.28 \pm 1.23^{b}$ & 0.007 \\
\hline & $b^{*}$ & $7.27 \pm 3.14$ & $6.37 \pm 0.22$ & 0.401 \\
\hline
\end{tabular}

a,b Means within a row with different superscripts differ significantly; $P$ - Probability $(P<0.05)$.

Table 2: Sensory quality of meat.

\begin{tabular}{lccc}
\hline & Meat control & Meat supplemented with thyme & $P$ value \\
\hline Color & $3.97 \pm 2.33^{\mathrm{b}}$ & $6.70 \pm 1.65^{\mathrm{a}}$ & 0.005 \\
Juiciness & $3.05 \pm 1.57$ & $4.70 \pm 2.38$ & 0.070 \\
Odour & $3.25 \pm 2.23^{\mathrm{b}}$ & $6.81 \pm 2.11^{\mathrm{a}}$ & 0.001 \\
Taste & $3.01 \pm 1.51^{\mathrm{b}}$ & $7.05 \pm 1.95^{\mathrm{a}}$ & \\
Tenderness & $3.81 \pm 1.34^{\mathrm{b}}$ & $6.179 \pm 1.73^{\mathrm{a}}$ & 0.0001 \\
Acceptability & $4.35 \pm 2.66^{\mathrm{b}}$ & $5.91 \pm 2.32^{\mathrm{a}}$ & 0.002 \\
\hline
\end{tabular}

\footnotetext{
a,b Means within a row with different superscripts differ significantly; $P$ - Probability $(P<0.05)$.
} 


\section{CONCLUSION}

In conclusion, the addition of thyme leaves did not affect the chemical composition of meat, but it highly affected the redness and improved the sensory quality of meat. This study was done just to compare the addition of thyme powder on the quality of the meat especially, the sensory quality, which is a common and traditional practice to improve the taste and smell of meat. Further analyses are required to study the impact of thyme leaves extract on meat stability and how it can help in extending the shelf life of meat products.

\section{REFERENCES}

Abdel Hamied, A.A., Nassar A.G., Elbadry, N. (2009). Investigations on antioxidant and antimicrobial activities of some natural extract. World Journal Dairy and Food Science. 4: 01-07.

Adam, A.A.G., Atta, M., Ismail, S.H.A. (2010). Quality and sensory evaluation of meat from Nilotic male kids fed on two different diets. Animal Science Journal. 107-112.

AOAC. (1995). Official Methods of Analysis, $15^{\text {th }}$ ed. AOAC (Association of Official Analytical Chemists), Washington, DC, pp. 69-88.

Bandoniene, D., Pukalskas, A., Venskutonis, P.R., Venskutonis, P.R., Gruzdiene, D. (2000). Preliminary screening of antioxidant activity of some plants extracts rapeseed oil. International Food Research Journal. 33: 785-791.

Dapkevicius, A., van Beek, T.A., Niederlander H.A.G. (1999). Evaluation and comparison of two improved techniques for the on-line detection of antioxidants in liquid chromatography eluates. Analytical Chemistry. 71: 736-740.
Dhanda, J.S., Taylor, D.G., Murray, P.J., Cosker, J.E. (1999). The influence of goat genotype on the production of Capretto and Chevon carcasses. 2. meat quality. Meat Science. 52: 363-367.

Hara, A., Radin, N. (1978). Lipid extraction of tissues with a low toxicity solvent. Analytical Chemistry. 90: 420-426.

Hijazeen, M., Rawashdeh, M. (2017). Preservative effects of rosemary extract (Rosmarinus officinalis L.) on quality and storage stability of chicken meat patties. Journal of Food Science and Technology. 39: 27-34.

Jama, N., Muchenje,V., Chimonyo, M., Strydom, P.E., Dzama, K., Raats, J.G. (2008). Cooking loss components of beef from Nguni, Bonsmara and Angus steers. Africain Journal of Agricultural Research. 416-420.

Jin, S.K., Choi, S.K., Lee, S.J., Lee, S.Y., Hur, S.J. (2006). Effect of Thyme and Rosemary on the quality characteristics, shelf life and residual nitrite content of sausages during cold Storage. Korean Journal of Food Science. 656-644.

Kannan, G., Kouakou, B., Gelaye, S. (2001). Color changes reflecting myoglobin and lipid oxidation in chevon cuts during refrigerated display. Small Ruminant Research. 42: 67-75.

Nieto, G., Diaz, P., Banon, S., Garrido, M.D. (2010). Effect on lamb meat quality of including thyme (Thymus zygis $s s p$ gracilis) leaves in ewes diet. Meat Science. 85: 82-88.

Normand, J., Moëvi, I., Lucbert, J., Pottier, E. (2005). Le point sur l'alimentation des bovins et des ovins et la qualité des viandes. Collection "Le point sur..." Interbev and L'institut de l'élevage, Paris.

Velasco, V., Williams, P. (2011). Improving meat quality through natural antioxidants. Chilean Journal of Agricultural Research. 71(2): 313-322. 